\title{
Wieder eine neue Bank im Palmengarten
}

Dank der Spende von Mitgliedern der Freunde des Palmengartens, die damit ihre Verbundenheit mit dem Palmengarten deutlich zeigen, konnte eine weitere neue Bank dem Palmengarten übergeben werden.
Wer sich angesprochen fühlt und auch eine Bank spenden möchte, kann sich gerne an die Freunde des Palmengartens wenden (E-Mail: info@palmengartengesellschaft.de oder telefonisch donnerstags von 15.30 bis $17.00 \mathrm{Uhr}$ unter (0 69) 745839).

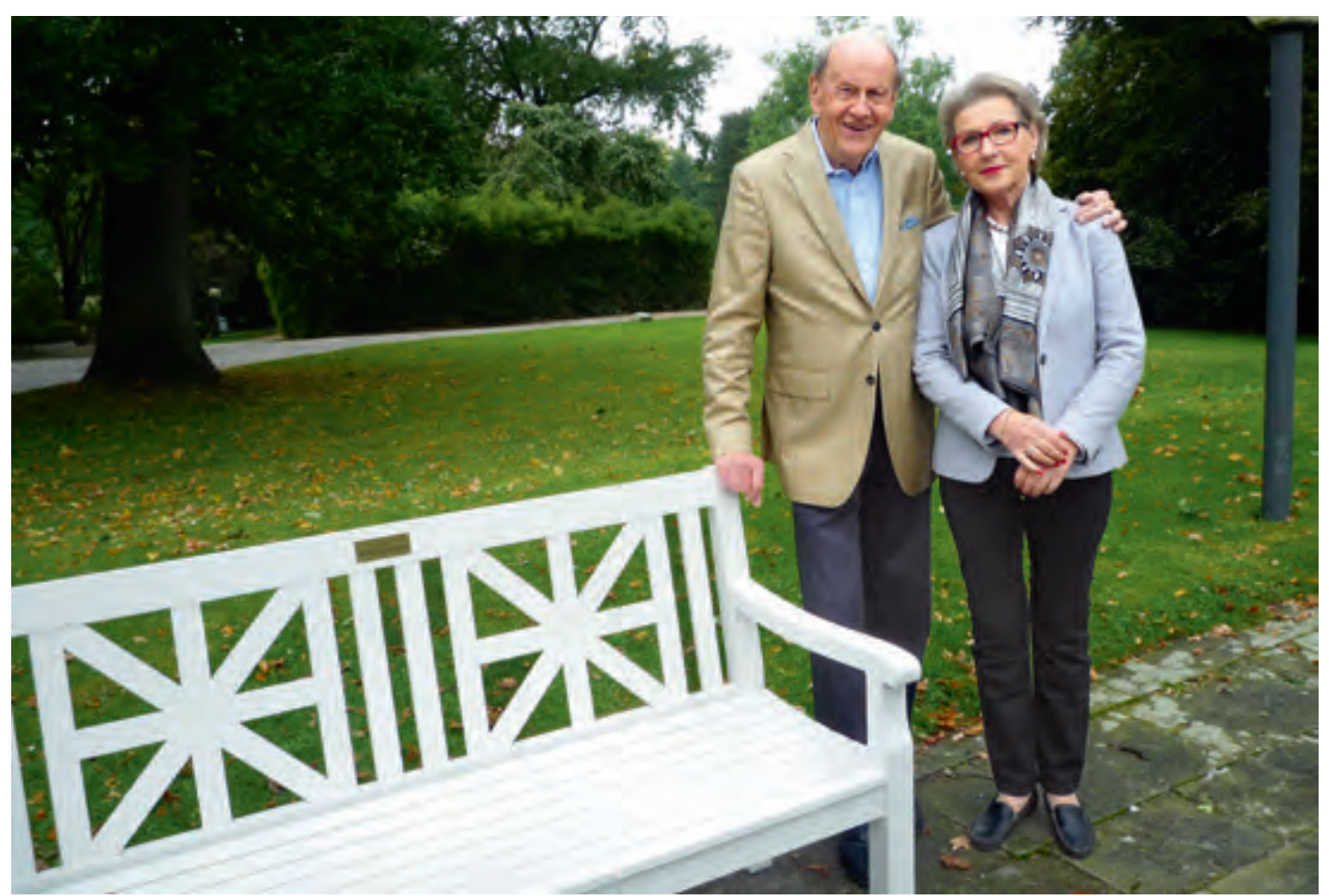

Abb. 1: Freude über die neue Bank. (Foto: L. Sebastian)

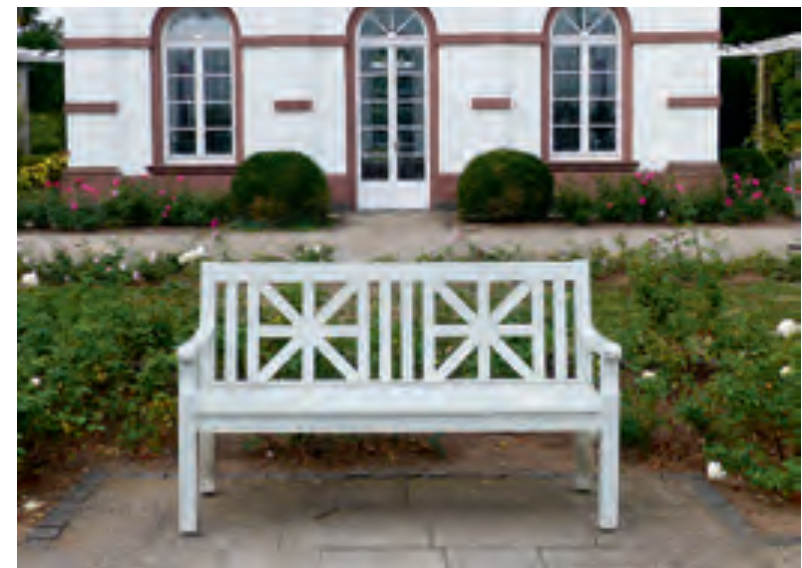

Abb. 2: Die Bänke im Rosengarten sind sehr beliebte Sitzplätze. (Foto: H. Steinecke)

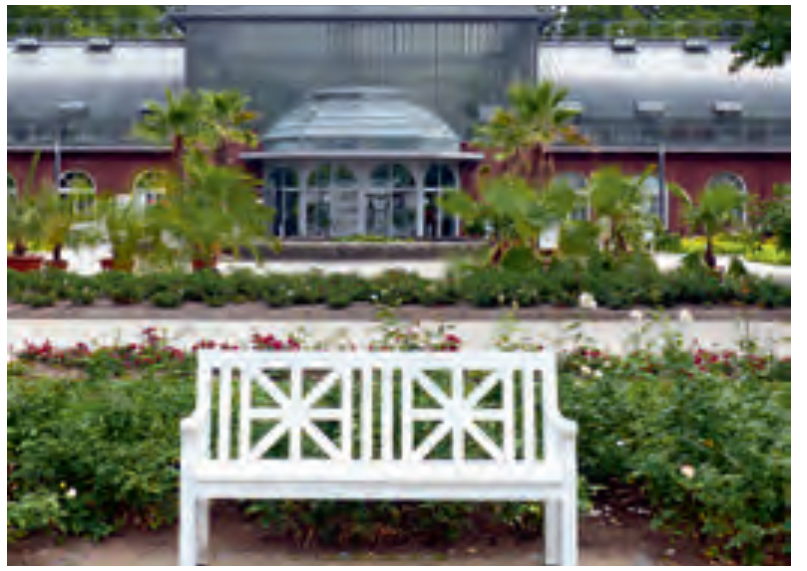

Abb. 3: Bank im Rosengarten, dahinter der Eingang Siesmayerstraße. (Foto: H. Steinecke) 